DOI: 10.19195/0137-1150.163.13

\author{
NEL BIELNIAK \\ Uniwersytet Zielonogórski, Polska \\ nel.bielniak@wp.pl
}

\title{
Oblicza starości w opowiadaniach Aleksandra Kuprina
}

Wbrew obiegowemu przeświadczeniu, że starość jest tematem niechętnie podejmowanym w badaniach literackich ${ }^{1}$, dysponujemy dziś pokaźną bibliografią prac z różnych dziedzin nauki (antropologii, demografii, estetyki, medycyny, psychologii czy socjologii), w tym także literaturoznawstwa, poruszających szeroko rozumianą problematykę schyłku ludzkiego życia². Wśród nich istotne miejsce zajmują monografie francuskich historyków idei, Georges’a Minois i Jeana-Pierre'a Bois, ukazujące kulturową historię starych ludzi od antyku do pierwszych lat XX wieku ${ }^{3}$, ,Starość”, jak konstatuje Bois, „tkwi w samym

${ }^{1}$ Zob. S. Kruk, Wprowadzenie, [w:] Dojrzewanie do petni życia. Starość w literaturze polskiej i obcej, red. S. Kruk, E. Flis-Czerniak, Lublin 2006, s. 23.

${ }^{2} \mathrm{~W}$ celu zaprezentowania różnorodności perspektyw metodologicznych i podkreślenia niemalejącej popularności problematyki gerontologicznej wśród badaczy wymieńmy tylko kilka publikacji: Encyklopedia seniora, red. F. W. Sawicka et al., Warszawa 1986; Dojrzewanie do petni życia...; Starość. Wybór materiatów z VII konferencji Pracowników Naukowych i Studentów Instytutu Nauk o Literaturze Polskiej UŚ, red. A. Nawarecki, A. Dziadek, Katowice 1995; R. Przybylski, Baśń zimowa. Esej o starości, Warszawa 1998; K. Trybuś, Stary poeta. Studia o Norwidzie, Poznań 2000; Trzeci wiek drugiej ptci. Starsze kobiety jako podmiot aktywności społecznej i kulturowej, red. E. Zierkiewicz, A. Łysak, Wrocław 2006; J. Améry, O starzeniu się: bunt i rezygnacja. Podnieść na siebie rękę: dyskurs o dobrowolnej śmierci, thum. B. Baran, Warszawa 2007; Egzystencjalne doświadczenie starości w literaturze, red. A. Gleń, I. Jokiel, M. Szladowski, Opole 2008; Młodość i starość. Integracja pokoleń, red. B. Bugajska, Szczecin 2010; Pamiętaj o swojej starości: materialy z konferencji naukowej „Starość w młodości - młodość w starości”, red. S. Rogala, Opole 2011; K. Uzar, Wychowanie w perspektywie starości: personalistyczne podstawy geragogiki, Lublin 2011; Poznać, zrozumieć i zaakceptować starość: wybór materiałów konferencyjnych, red. A. Zych, Łask 2012.

${ }^{3}$ G. Minois, Historia starości: od antyku do renesansu, tłum. K. Marczewska, Warszawa 1995; J.-P. Bois, Historia starości: od Montaigne’a do pierwszych emerytur, tłum. K. Marczewska, Warszawa 1996. 
sercu zasadniczej dwuznaczności ludzkiego losu: u kresu starości znajduje się zawsze śmierć. Co do tego panuje powszechna zgodność. [...] starość to wrota do nicości lub do wieczności. Wszystko inne jest przedmiotem sporów"4, które wynikają z indywidualnego doświadczania starości przez jednostkę. Starość jest bowiem w głównej mierze „osobistym przeżyciem każdego człowieka, a dopiero później wytworem określonego społeczeństwa czy też kultury, choć każda grupa społeczna czy typ rodziny jest źródłem dominujących wzorców"5. Stąd też wielka liczba koncepcji starości, z jaką mamy do czynienia także w tekstach literackich, na które, jak sugeruje Marek Szladowski, warto spojrzeć jak na kulturowe zapisy ludzkiej egzystencji, otwierające szeroką przestrzeń interpretacyjną ${ }^{6}$.

Dziewiętnastowieczna literatura europejska obfituje w różnorodne opisy starości, schyłku życia i śmierci, zróżnicowane w zależności od kulturowych, społecznych i narodowych realiów. Starość rosyjska różni się bowiem od angielskiej czy francuskiej, a starość arystokraty — od starości chłopa. Charles Dickens, Oscar Wilde, Thomas Mann, Guy de Maupassant, Honoré de Balzac, Victor Hugo, Emil Zola, a także rodacy Puszkina - Nikołaj Gogol, Iwan Turgieniew, Fiodor Dostojewski, Lew Tołstoj czy Anton Czechow — odmalowują na kartach swych utworów rozmaite wersje starości: od ubogiej po dostatnią, od nieszczęśliwej po pogodną, od niegodziwej po poczciwą, od serdecznej po zrzędliwą et cetera. Na styku stuleci w rosyjski dyskurs na temat starości włączają się między innymi Maksim Gorki, Iwan Bunin i Aleksandr Kuprin, którzy kontynuują tradycje wspomnianych klasyków.

Autor Olesi wielokrotnie dotyka zagadnienia zmierzchu życia, przemijania, choroby i śmierci zarówno w twórczości literackiej, jak i ego-dokumentach? W epistolografii częstotliwość występowania tej tematyki wyraźnie nasila się podczas emigracji, wtedy bowiem pisarz osobiście doznaje starości. Na przykład w liście napisanym w 1924 roku do Kseni, córki z drugiego małżeństwa, Kuprin łączy motywy starości, choroby i śmierci:

\footnotetext{
${ }^{4}$ J.-P. Bois, op. cit., s. 313.

5 Ibidem.

${ }^{6}$ M. Szladowski, Starość w przedsionku śmierci (zamiast wstępu), [w:] Egzystencjalne doś-
} wiadczenie starości..., s. 9.

${ }^{7}$ Por. С. Ташлыков, А.И. Куприн: поэтика новелль, Иркутск 2012, s. 30-44; E. Sławęcka, Inspiracje naturalistyczne w twórczości Aleksandra Kuprina, [w:] Zagadnienia prąów i kierunków w literaturze rosyjskiej, red. S. Poręba, Katowice 1980, s. 99-101; N. Bielniak, Śmierć $i$ choroba $w$ opowiadaniach Aleksandra Kuprina ( $w$ świetle refleksji społeczno-psychologiczno-kulturowych), „Studia Wschodniosłowiańskie” 2014, nr 14, s. 15-28; N. Bielniak, Motywy tanatologiczne w opowiadaniach Aleksandra Kuprina, [w:] Studia wschodniosłowiańskie: literatura i język, red. A. Ksenicz, M. Łuczyk, N. Bielniak, A. Urban-Podolan, Zielona Góra 2014, s. 49-61. N. Bielniak, Metafizyka życia i śmierci w opowiadaniach Aleksandra Kuprina, „Rusycystyczne Studia Literaturoznawcze" 2014, nr 24, s. 77-90. 
Стыдно моя дорогая девочка, смеяться над старостью. Во-первых, сама такой будешь. Во-вторых, старость - одна из самых скверных, тяжелых болезней, да вдобавок она ничем не излечима, кроме смерти ${ }^{8}$.

Kwestię upływu czasu i nękających go dolegliwości prozaik porusza niejednokrotnie także w listach z lat 1928-1934 do mieszkającego w USA Iosifa Lewinsona, postrzega w nich siebie jako zniedołężniałego sześćdziesięciolatka, co po prawdzie nie odbiega od rzeczywistości ${ }^{9}$. Wiosną 1931 roku autor Pojedynku nie po raz pierwszy narzeka na nieodłączną towarzyszkę starości - chorobę, która spowodowała długą przerwę w korespondencji: „Причина — омерзительная французская зима. Сначала провертел меня насквозь дьявольский ишиас, потом измучил сорокаградусный грипп, потом привязалась нервная экзема" 10 .

Niekiedy wypowiedzi prozaika zabarwione są żartobliwie. Na przykład w liście z połowy 1932 roku Kuprin utyskuje na wiek, który przyczynia się do utraty przez niego atrakcyjności w oczach przedstawicielek płci pięknej: „Жаль, что мне не 40, а 60 лет. А то бы черт возьми, наделал бы я множество побед над парижанками!" 11.

Natomiast w liście napisanym wiosną 1930 roku pod wpływem zmiany pór roku, symbolizującej wieczny kołowrót narodzin i śmierci ogarnia Kuprina nastrój filozoficzny, dlatego też oddaje się on rozmyślaniom nad życiem i śmiercią:

И как всегда весною любуюсь и грущу: неужели последняя моя весна? Ну, что же? Неизбежно - неизбежно. Ни плакать, ни сопротивляться, ни трусить не будем, хотя, конечно, не отказался бы сладко погрустить, и еще одну весну, еще последнюю. Ах! великолепная штучка жизнь ${ }^{12}$.

Co istotne, w prywatnej korespondencji do Lewinsona uwydatniają się dwa reprezentatywne dla całej twórczości Kuprina sposoby myślenia o starości; uciekając się do uogólnienia, można je określić jako naturalistyczny i metafizyczny. $\mathrm{Z}$ jednej strony mamy do czynienia z listą chorób i ich objawów, z drugiej zaś -

${ }^{8}$ Переписка И.Е. Репина и А.И. Куприна, публикация и комментарии К. Куприной, „Новый мир” 1969, nr 9, s. 201.

${ }^{9}$ Wśród wielu nękających wówczas Kuprina chorób można wymienić przemieszczenie siatkówki, postępującą sklerozę, niedokrwienie mózgu, problemy z poruszaniem się i w ostatnim okresie rak przewodu pokarmowego. Wszystko to sprawiło, że pod koniec życia całkowicie uzależniony był od pomocy innych osób, głównie żony. Por. Ю. Дружников, Куприн в дегте и патоке, „Новое русское слово”, 24.02.1989, http://gatchina3000.ru/literatura/kuprin_a_i/17 kuprin_in_tar_and_treacle.htm [dostęp: 12.07.2015]; Н.А. Тэффи, Моя летопись, http://www. vek-serebra.ru/teffi/moia_letopis.htm [dostęp: 12.07.2015]; А. Седых, А.И. Куприн, http://www.a-port.us/gene/story/seduh.htm [dostęp: 12.07.2015].

10 Письма А.И. Куприна к И.А. Левинсону (1928-1934 г2.), [w:] К.Н. Батюшков, Ф.Д. Батюшков, А.И. Куприн. Материаль всероссийской научной конференции в Устюжне о жизни и творчестве Батюшковых и Куприна (28-29 сентября 1966 года), публикация и комментарии П. Ширмакова, Вологда 1968, s. 161.

11 Ibidem, s. 165.

12 Ibidem, s. 158. 
z rozważaniami o mijającym nieuchronnie życiu i podeszłym wieku. Prozaik nie boi się nadchodzącego kresu, lecz żałuje, że wraz z upływającym czasem coraz bardziej zawęża się krąg umiejętności i przyjemności, z których może korzystać. Jest to dla niego szczególnie trudne, ponieważ zawsze chętnie czerpał z życia pełnymi garściami. Nieprzypadkowo Ilja Riepin porównywał młodego Kuprina do Bachusa:

Тогда еще очень молодой Куприн казался мне похожим на молодого Вакха. [...] А какая силища, какая мускулатура! Такие форы бицепсов и дельт не спрятать: все сквозит под рубашкой. И мне чувствовался всегда такой вес в этом Дионизосе! ${ }^{13}$

W beletrystyce autora Pojedynku brakuje cezury oznaczającej początek starości, nie ma też ona precyzyjnie określonego wieku. Jej ucieleśnieniem są zarówno czterdziestoletni, jak i siedemdziesięcioletni bohaterowie. Niekiedy tożsamość starego człowieka wyznacza w opowiadaniach Kuprina nie wiek, lecz praca. Za przykład może tu posłużyć posunięte w latach korsykańskie małżeństwo z cyklu szkiców Lazurowe wybrzeża (Лазурные берегa, 1913), które prowadzi w Bastii niedrogą, lecz cieszącą się dobrą sławą jadłodajnię. Własny interes jest źródłem zarówno niezależności finansowej staruszków, jak i wigoru oraz wewnętrznej harmonii. Jest też starość w utworach Kuprina, o czym nie należy zapominać, zapisem osobistych przeżyć istoty ludzkiej. Wszystko to warunkuje mnogość literackich wizerunków ludzi starych i starzejących się, a także pozwala pokusić się o pewną klasyfikację obrazów starości w jego utworach.

Bohaterowie opowiadań Kapłan (Жрец, 1905) i Lenka (Леночка, 1910) niejako potwierdzają tezę, że starość to nie wiek, lecz stan umysłu. Obaj w wieku czterdziestu pięciu lat zaczynają odczuwać nieubłagany upływ czasu, co prowokuje ich do stawiania pytań natury egzystencjalnej. Autor wprowadza tu motyw przedwczesnej starości, powolnego więdnięcia ducha. Bohatera Lenki mimo dobrej kondycji fizycznej i witalności nękają myśli o własnej śmierci, dlatego też przestają go cieszyć radości życia, kobiece wdzięki, a miejsce niefrasobliwości zajmuje rozwaga i drobiazgowe analizowanie każdej z podejmowanych decyzji. Ukojenie przynosi Woznicynowi tylko zaskakujące go spostrzeżenie o pięknie i mądrości życia z wpisanym w nie nieskończonym cyklem narodzin i umierania. Natomiast Czudinowa z pierwszego utworu drażni wszystko to, co wcześniej było natchnieniem i silnym impulsem do pracy: szpitalne zapachy, pacjenci, zaufanie, jakim go darzą, ich wiara w jego zdolności i moc uzdrawiania. Teraz towarzyszą mu głównie samotność, przygnębienie i bliżej nieokreślony smutek:

Чудинов поймал себя на дурных мыслях и подумал то, что часто думал за последнее время: „Да, это старость подходит... преждевременная старость в сорок пять лет. Раньше все было впереди, теперь нечего ждать, и организм требует грубых удовольствий, простой, несложной жизни..." 14

13 Переписка И.Е. Репина и А.И. Куприна..., s. 195.

14 А. Куприн, Жреи, [w:] idem, Собрание сочинений в девяти томах, т. 3, Москва 19701973, s. 426-427. 
Uznany lekarz nie deprecjonuje ani wiedzy, ani wypływających z niej umiejętności i korzyści. Uświadamia sobie po prostu, „że to nie wiedza stanowi o smaku i znaczeniu naszych czynów"15.

Nurtujące bohaterów Kapłana i Lenki kwestie przemijania, upływu czasu, sensu życia i śmierci są także lejtmotywem opowiadania Mój paszport (Moŭ nacnopm, 1908), w którym uwypuklony został dodatkowo problem zmiany skali wartości oraz znaczenia, jakiego nabierają wspomnienia z przeszłości u ludzi w podeszłym wieku.

Kontemplacyjność i refleksyjność bohaterów wspomnianych utworów odsyła nas niejako do Schopenhauerowskiego podziału życia na poszczególne okresy. Niemiecki filozof za zasadnicze kryterium podziału przyjmuje właśnie skłonność do kontemplacji. W jego mniemaniu około czterdziestki rozpoczyna się okres melancholii, wtedy też popadają w zapomnienie namiętności i ambicje, a człowiek wkracza w starość - etap uspokojenia, który może być szczęśliwy, jeśli zdrowie i pieniądze zastąpią brakujące siły ${ }^{16}$.

Dobrze sytuowani bohaterowie około pięćdziesiątki, zdający sobie sprawę $\mathrm{z}$ uciekającego bezpowrotnie czasu, pojawiają się między innymi w utworach $\mathrm{Pe}$ tentka (Просительница, 1895) oraz Taper (Tanep, 1900), w których występuje motyw niezgody na starość. Bohaterowie za wszelką cenę starają się zatrzymać młodość: dbają o swój wygląd zewnętrzny, ubierają się elegancko, choć są żonaci, lubią używać życia i cieszyć się towarzystwem ślicznych kobiet, co bardzo ułatwia im sytuacja materialna i pozycja społeczna. Rudniew z Tapera to pewny siebie, postawny bawidamek, który uwielbia spędzać czas z młodzieżą, to bowiem zdaje się być swoistym remedium na przemijanie. Bohater Petentki z kolei odmalowany został jako podstarzały lubieżnik, któremu sprawia przyjemność poczucie władzy nad ludźmi słabszymi i uzależnionymi od niego:

Кое-где пробивается седина, в общем, вид очень внушительный, а главное, особенно сегодня, он чувствует себя молодым назло годам. Константин Петрович человек богатый, с положением, со связями; от него зависят судьбы других маленьких людей, и все блага жизни к его услугам, он это сознает и очень ценит ${ }^{17}$.

Portrety takich podstarzałych lub starych satyrów reprezentujących różne środowiska i grupy społeczne (arystokratów, urzędników, prowincjonalnych aktorów) pojawiają się również w opowiadaniach Ku sławie (K славе, 1894), U końca (На покое, 1902), Odurzenie (Угар, 1904) czy Na rozjeździe (На разъезде, 1894). W ostatnim z nich poruszony został częsty u Kuprina wątek młodej, niedoświadczonej dziewczyny wydanej za mąż wbrew jej woli za człowieka antypatycznego i wulgarnego. Istotną rolę odgrywają tu kwestie ekonomiczne: stary i bogaty bierze za żonę młodą i biedną, oczekując w zamian dozgonnej

15 T. Sławek, Traktat starego człowieka. Próba polityki starości, [w:] Egzystencjalne doświadczenie starości..., s. 27.

16 J.-P. Bois, op. cit., s. 279.

17 А. Куприн, Просительница, [w:] idem, Собрание сочинений..., т. 1, s. 266. 
wdzięczności i posłuszeństwa. Tragiczna historia kobiety uwikłanej w trudne relacje ze starszym o czterdzieści lat okrutnym mężczyzną została zaprezentowana także w opowiadaniu Spokojny żywot (Мирное житие, 1904). Zgoła inaczej pisarz potraktował ten temat w Strasznej chwili (Страшная минута, 1895). Tu również portretuje małżeństwo, które dzieli spora różnica wieku. Małżonków łączą wprawdzie wzajemny szacunek oraz ciepłe, serdeczne więzi, śpią jednak w osobnych sypialniach i zwracają się do siebie w szczególny sposób, dobrze charakteryzujący ich związek. Tak oto Riazancew mówi do żony: „Какая ты сегодня красавица, моя девочка, - сказал он, ласково ей улыбаясь” ${ }^{\prime 18}$. Ona zaś pyta go: „Ты мной доволен, папа? - спросила она, нежно притрагиваясь пальцами к его маленькой жилистой руке"19.

Kontrast między powierzchownością Warwary i jej męża pozwala pisarzowi uwydatnić w Strasznej chwili rozziew pomiędzy młodością a starością. Na tle wdzięcznych i jędrnych kształtów ślicznej, szczupłej szatynki o pełnych ustach niekorzystnie błyszczy wielka łysina Riazancewa z czerwonymi żyłkami, głębokie zmarszczki i żółtawy odcień jego przywiędłych policzków. Tu, w przeciwieństwie do Kapłana i Lenki, gdzie była mowa o starości mentalnej, mamy do czynienia ze starością somatyczną. Zasygnalizowane przemiany związane są bowiem z typową dla osób starych ogólną atrofią całej postaci. Z wiekiem skóra staje się coraz bardziej sucha i pomarszczona, włosy rzedną i siwieją, z ust wypadają zęby, ciało zmniejsza objętość. Pojawiają się zmiany zwyrodnieniowe, powodujące między innymi gromadzenie się pigmentu lub tkanki tłuszczowej, co pociąga za sobą zniekształcenie rysów twarzy ${ }^{20}$.

$\mathrm{Na}$ antynomii młodości i starości zasadzają się również fabuły utworów, w których wprowadzona zostaje para złożona ze starca i dziecka. Obrazy chłopców i staruszków pojawiają się między innymi w opowiadaniach Biaty pudel (Бельй пудель, 1903), Nad rzeka (На реке, 1896) і Koniokrady (Конокрады, 1903). W pierwszym opowiadaniu rozkwitająca młodość i więdnąca starość, podobnie jak w Strasznej chwili, zobrazowane zostały poprzez zestawienie werystycznych opisów obnażonych ciał głównych bohaterów przygotowujących się do kąpieli w morzu. Pogodny, pełen energii dwunastolatek przedstawiony został następująco: „Он быстро разделся, звонко хлопнул себя ладонями по голому, шоколадному от загара телу и бросился в воду, подымая вокруг себя бугры кипящей пены" 21.

Symbolizującej witalność opaleniźnie Sierioży, a także jego zwinności i szybkości przeciwstawione są powolne ruchy rachitycznego kataryniarza o niezdrowym, żółtym odcieniu skóry. Łodyżkin wydaje się wzorcową egzemplifikacją uwiądu starczego:

\footnotetext{
18 А. Куприн, Страшная минута, [w:] idem, Собрание сочинений..., т. 1, s. 288.

${ }^{19}$ Ibidem, s. 289.

20 J.-P. Bois, op. cit., s. 251.

21 А. Куприн, Страшная минута, [w:] idem, Собрание сочинений..., т. 1, s. 288.
} 
Дедушка долго постоял на солнышке, щупая у себя под мышками. В воду он сошел очень осторожно и, прежде чем окунуться, старательно мочил себе красное лысое темя и впалые бока. Тело у него было желтое дряблое и бессильное, ноги поразительно тонкие, а спина с выдавшимися острыми лопатками была сгорблена от долголетнего таскания шарманки ${ }^{22}$.

Leciwi bohaterowie Białego pudla i Nad rzeka, choć nie są spokrewnieni $\mathrm{z}$ chłopcami, pełnią ponadto funkcję kochających dziadków. Autor wyposaża ich we wszystkie atrybuty dobrego dziadunia: dobrotliwość, opiekuńczość, umiejętność snucia zajmujących opowieści. Członkowie wędrownej trupy — kataryniarz, dwunastoletni sierota i tytułowy pudel Arto — stanowią nietypową, lecz szczęśliwą i dbającą o siebie rodzinę, a Łodyżkin często zabawia Sieriożę anegdotami o egzotycznych miejscach i ludziach. Tymczasem stary kucharz z drugiego utworu wtajemnicza dziesięciolatka w magiczny świat nocnej przyrody, wypraw na raki bez wiedzy rodziców i niesamowitych, pełnych grozy opowieści o rozbójniku, o którym legendy przetrwały do dziś wśród miejscowej ukraińskiej ludności. Wszystko to pobudza wyobraźnię małego bohatera i wpływa na odmienne postrzeganie przez niego dobrze znanej rzeczywistości: „Хорошо знакомые кусты бурьяна казались толпою обступивших нас со всех сторон призраков, тонких и расплывчатых"23.

$\mathrm{Z}$ analogiczną sytuacją mamy do czynienia w Bransoletce z granatów (Гранатовый браслет, 1910), gdzie Kuprin zdaje się głosić pochwałę zarówno starości, jak i wieku dziecięcego. W utworze tym nakreślona została postać srebrnowłosego generała Anosowa, człowieka minionej epoki, odważnego i cierpliwego, a przy tym dobrodusznego i wesołego, którego dorosłe teraz siostry Wiera i Anna od najmłodszych lat ubóstwiają i poważają. Towarzysz broni ich ojca zawsze miał dla nich czas, chętnie brał udział w zabawach, rozpieszczał je i obsypywał prezentami. Dziewczynki najbardziej jednak lubiły i, co istotne, lubią do tej pory, opowiadane przez niego barwne historie:

Но больше всего их очаровывали и крепче всего запечатлелись в их памяти его рассказы о военных походах, сражениях и стоянках на бивуаках, о победах и отступлениях, о смерти, ранах и лютых морозах, - неторопливые, эпически спокойные, простосердечные рассказы, рассказываемые между вечерним чаем и тем скучным часом, когда детей позовут спать 24 .

Natomiast zdecydowanie inaczej Kuprin ukazuje relacje między spokrewnionymi bohaterami Koniokradów. Trudno tu mówić o ciepłych stosunkach łączących dziadka i trzynastoletniego wnuka. Autor podkreśla negatywną rolę staruszka, który miast chronić chłopca, wprowadza go w niebezpieczny świat złodziei, za pomoc którym można zapłacić nawet życiem. Opowiadanie to przynosi ponadto dwa inne wizerunki starości: starość samotną i opuszczoną oraz starość naznaczoną szaleństwem. Wasyla i jego dziadka Onisima dotyka ostracyzm

22 Ibidem, s. 279.

23 А. Куприн, На реке, [w:] idem, Собрание сочинений..., т. 2, s. 25.

24 А. Куприн, Гранатовый браслет, [w:] idem, Собрание сочинений..., т. 5, s. 236-237. 
społeczny, nędzarze nie cieszą się bowiem szacunkiem, dlatego też mieszkają na skraju wsi w rozpadającej się, zmurszałej chatynce wraz ze stuletnią, głuchą i zdziecinniałą staruchą. Świadectwem ich wykluczenia ze środowiska jest właśnie zajmowane przez nich lokum:

Все трое пользовались жильем бесплатно, из милости односельчан, тем более что в эту же вымороченную хату, по распоряжению начальства, свозили со всей волости, для вскрытия, удавленников, утопленников, скоропостижно умерших и убитых в драке крестьян. Тот самый стол, на котором обыкновенно обедали трое отщепенцев деревенской жизни, служил в этих случаях для помещения трупов ${ }^{25}$.

Ucieleśnieniem starości niepojętej i niechcianej jest również bohaterka mikropowieści Olesia (Олеся, 1898). Manujlicha jest w tych stronach obca, a jej odmienne i niezrozumiałe zachowanie oraz sposób mówienia wywołują lęk, dlatego też miejscowa poleska ludność obwinia ją o wszystkie nieszczęścia, a następnie przegania wraz z wnuczką ze wsi. Nie jest ona ponadto traktowana jako „nasza”, gdyż starość utożsamiana jest nierzadko z czymś groźnym i niepokojącym ${ }^{26}$. Kultura, jak zauważa Tadeusz Sławek, „lokuje starego człowieka na obrzeżach i marginesach już to jako niezdolnego do uczestniczenia w dalszym życiu społeczności, już to jako przedstawiciela sił zagrażających porządkowi świata"27.

Manujlicha $z$ uwagi na otaczającą ją aurę tajemniczości, zamieszkiwanie w leśnych ostępach oraz powierzchowność baśniowej Baby-Jagi umiejscowiona zostaje niejako na pograniczu człowieczeństwa. Niezwykły wygląd i sposób bycia tej starej kobiety, a także przenikliwość spojrzenia sprawiają, że główny bohater przez krótką chwilę odczuwa strach czy nawet wstręt, zdaje mu się bowiem, że ma do czynienia z osobą obłąkaną. O antypatii, jaką młodzi ludzie nierzadko odczuwają w stosunku do osób sędziwych, wspomina też u schyłku życia autor Burłaków na Wołdze:

Да, недаром я еще с юности не любил стариков, только не подумайте, что великих стариков, - тех я обожал, а так, шевелящихся старичков вроде меня, что еще не прочь поправиться в своей безнадежной походке - совестно им уже на людях фигурировать ${ }^{28}$.

Do osamotnienia, odtrącenia, fizycznej zgrzybiałości i obłędu składających się w utworach Kuprina na ponurą wizję starości dochodzą jeszcze w opowiadaniu U końca (На покое, 1902) zgorzkniałość i złośliwość. Jego akcja toczy się w przytułku dla bezdomnych aktorów. Rytm dnia wyznaczają pory posiłków, a pięciu schorowanych i zgryźliwych mieszkańców zabija czas, głównie dokuczając sobie i grając w karty, choć niekiedy zdarza im się wracać pamięcią w przeszłość i podejmować próby podsumowania bezpowrotnie utraconego życia. Na-

25 А. Куприн, Конокрады, [w:] idem, Собрание сочинений..., т. 3, s. 256.

${ }^{26}$ Zob. J. Błuszkowski, Stereotypy a tożsamość narodowa, Warszawa 2005, s. 15-31; T. Sławek, op. cit., s. 16-17.

27 T. Sławek, op. cit., s. 18.

28 А. Куприн, На реке, [w:] idem, Собрание сочинений..., т. 2, s. 25. 
cechowany pejoratywnie obraz zgorzkniałej i zniedołężniałej starości wzmacnia prozaik, wykorzystując bodźce zmysłowe:

Венецианских окон никогда не отворяли из боязни сквозняка, от этого в комнате прочно установился запах нечистоплотной, холостой старости - запах застоявшегося табачного дыма, грязного белья и больницы ${ }^{29}$.

Kolejne negatywne oblicze starości, tym razem świętoszkowatej i obłudnej, przynosi opowiadanie Spokojny żywot. Główny bohater niczym Bielikow z noweli Czechowa trzyma w strachu lokalną społeczność. Całymi dniami z wyraźną przyjemnością pisze donosy na mieszkańców miasteczka pod pretekstem ochrony dobrych obyczajów, prowadzi też rejestr niewłaściwych zachowań. Nasiedkin przekonany jest o słuszności swojego postępowania, lecz obojętność na losy ludzi, których krzywdzi, przejawia się nawet w jego charakterze pisma. Gdy po drodze do cerkwi wyprzedza go grupka gimnazjalistów pod opieką młodego nauczyciela o przyjaznym spojrzeniu z papierosem w ustach, Nasiedkin z typową dla siebie zawziętością i zgryźliwością natychmiast odnotowuje w myślach:

И это называется идти в храм, да еще в такие дни! — с горечью и укоризной подумал Иван Вианорыч. — И это учитель, педагог! Развращенный вид, папироса во рту! Кажется, его фамилия Добросердов?.. Нечего сказать, хорош... Буду иметь его в виду, на всякий случай ${ }^{30}$.

Takie negatywne zachowania, jak: zgryźliwość, drażliwość, zdziwaczenie, podejrzliwość czy upór, pojawiające się lub nasilające u niektórych osób w podeszłym wieku, krytykował już Cyceron, poruszający w swych traktatach filozoficznych problem starości. Jak konstatuje Henryk Kowalski, ten rzymski myśliciel i orator poczytywał je wszakże za indywidualne wady charakteru niezwiązane z wiekiem. Natomiast za największą zaletę starości uznawał Cyceron szacunek i poważanie, które zdobywa się już od wczesnych lat poprzez swoje działania, oraz możliwość udzielania rad młodemu pokoleniu, zwłaszcza własnym dzieciom ${ }^{31}$.

Kuprinowscy staruszkowie nie zawsze bywają samotni i odrzuceni, cieszą się również zasłużoną estymą i miłością niezależnie od ich statusu majątkowego. Odtrącona przez społeczeństwo Manujlicha jest bardzo kochana i otaczana opieką przez wnuczkę. Podobne stosunki łączą żyjących na skraju nędzy wędrownych artystów z Białego pudla. Z atencją, jaką otaczają generała Anosowa Wiera i Anna, mamy również do czynienia w mikropowieści Chorą̇y (Прапорщик армейский, 1897). Tu rodzina miejscowego bogacza, właściciela cukrowni, z szacunkiem i serdecznością odnosi się do seniorki rodu. Natomiast opowiadanie Czary $($ Yapbl, 1897) przynosi arkadyjski obrazek zgodnej, zadowolonej wielopokoleniowej rodziny:

29 А. Куприн, На покое, [w:] idem, Собрание сочинений..., т. 3, s. 174.

30 А. Куприн, Мирное житие, [w:] idem, Собрание сочинений..., т. 3, s. 305.

${ }^{31}$ H. Kowalski, Spokój czy smutek? Koncepcja starości w pismach Marka Tulliusza Cycerona, „Vox Patrum” 56, 2011, s. 126, http://www.voxpatrum.pl/pdfy/Vox56/Kowalski.pdf [dostęp: 11.07.2015]. 
Глядя на эту невинную забаву, и толстая женщина, и старушка с чулком, и сам „Паганини” улыбались блаженными улыбками, улыбками счастливого отца, довольной матери и бабушки, пользующейся в доме заслуженным почетом ${ }^{32}$.

Nierzadko leciwych bohaterów cieszących się autorytetem wyposaża Kuprin w mądrość — przysłowiowy przymiot podeszłego wieku ${ }^{33}$. Do grona takich postaci — szanowanych, o wielkim doświadczeniu i wiedzy — zaliczyć można między innymi profesora Sławin-Sławinskiego z opowiadania Ku sławie oraz wybitnego kompozytora z Tapera i słynnego chirurga z Cudownego doktora (Чудесный доктор, 1897). Dwaj ostatni bohaterowie wzorowani są na realnych postaciach - Antona Rubinsteina i Nikołaja Pirogowa. Pirogow sportretowany został jako niewysoki, dobrotliwy, szczodry, empatyczny staruszek, który bezinteresownie pomaga ubogiej rodzinie. Natomiast w charakterystykach profesora i pianisty uwagę zwraca ich osobliwa fizjonomia przywodząca na myśl lwa. O Sławinskim czytamy: „косматая грива седых волос, смелые глаза и широкие ноздри ${ }^{34 ”,}$, oto co pisze Kuprin o Rubinsteinie: „Общее впечатление довершала длинная грива густых, небрежно заброшенных назад волос, делавшая эту характерную, гордую голову похожей на львиную...”35.

Odwołanie się do symboliki lwa jest, jak się zdaje, w pełni uzasadnione, albowiem lew to uosobienie rozumu, majestatu i dumy, symbol szlachetności, sprawiedliwości i szczodrości ${ }^{36}$. Bez wątpienia tymi cechami mogą się poszczycić wspomniani bohaterowie.

Na zakończenie powołam się na Immanuela Kanta, który stwierdza, że „szacunek okazywany starości nie jest motywowany respektem dla siwych włosów ani dla kruchości sędziwego ciała. Nasz szacunek nie jest odpowiedzią na słabość organizmu. Wprost przeciwnie — honorując starego człowieka, podziwiamy siłę bytu zatrzymującego życie"37.

\section{Bibliografia}

Améry J., O starzeniu się: bunt i rezygnacja. Podnieść na siebie rękę: dyskurs o dobrowolnej śmierci, tłum. B. Baran, Warszawa 2007.

Bielniak N., Metafizyka życia i śmierci w opowiadaniach Aleksandra Kuprina, „Rusycystyczne Studia Literaturoznawcze" 2014, nr 24.

32 А. Куприн, Чapы, [w:] idem, Собрание сочинений..., т. 2, s. 150-151.

${ }^{33}$ Upatrywanie w rozumie skarbu najcenniejszego ma biblijne praźródło. Niemal we wszystkich księgach dydaktycznych Starego Testamentu mowa jest o wielkim znaczeniu mądrości. Takie oto słowa odnaleźć można m.in. w Księdze Hioba: „Nie dorówna jej ani złoto, ani szkło, nie można jej zamienić na kosztowności szczerozłote. Perły i kryształy nie wchodzą przy niej w rachubę, bo większą wartość ma zdobycie mądrości niż perły" (Hiob 28, 17-18).

34 А. Куприн, К славе, [w:] idem, Собрание сочинений..., т. 1, s. 206.

35 А. Куприн, Tanep, [w:] idem, Собрание сочинений..., т. 3, s. 83.

36 W. Kopaliński, Stownik symboli, Warszawa 2006, s. 191.

37 Cyt. za: T. Sławek, op. cit., s. 31. 
Bielniak N., Motywy tanatologiczne w opowiadaniach Aleksandra Kuprina, [w:] Studia wschodniosłowiańskie: literatura i język, red. A. Ksenicz, M. Łuczyk, N. Bielniak, A. Urban-Podolan, Zielona Góra 2014.

Bielniak N., Śmierć i choroba w opowiadaniach Aleksandra Kuprina (w świetle refleksji spoleczno-psychologiczno-kulturowych), ,Studia Wschodniosłowiańskie” 2014, nr 14.

Błuszkowski J., Stereotypy a tożsamość narodowa, Warszawa 2005.

Bois J.-P., Historia starości: od Montaigne'a do pierwszych emerytur, tłum. K. Marczewska, Warszawa 1996.

Dojrzewanie do petni życia. Starość w literaturze polskiej i obcej, red S. Kruk, E. Flis-Czerniak, Lublin 2006.

Egzystencjalne doświadczenie starości w literaturze, red. A. Gleń, I. Jokiel, M. Szladowski, Opole 2008.

Encyklopedia seniora, red. F.W. Sawicka et al., Warszawa 1986.

Kopaliński W., Stownik symboli, Warszawa 2006.

Kowalski H., Spokój czy smutek? Koncepcja starości w pismach Marka Tulliusza Cycerona, „Vox Patrum" 2011, nr 56.

Kruk S., Wprowadzenie, [w:] Dojrzewanie do petni życia. Starość w literaturze polskiej i obcej, red S. Kruk, E. Flis-Czerniak, Lublin 2006.

Minois G., Historia starości: od antyku do renesansu, tłum. K. Marczewska, Warszawa 1995.

Młodość i starość. Integracja pokoleń, red. B. Bugajska, Szczecin 2010.

Pamiętaj o swojej starości: materiaty z konferencji naukowej „Starość w młodości - młodość w starości”, red. S. Rogala, Opole 2011.

Poznać, zrozumieć i zaakceptować starość: wybór materiałów konferencyjnych, red. A. Zych, Łask 2012.

Przybylski R., Baśń zimowa. Esej o starości, Warszawa 1998.

Sławek T., Traktat starego człowieka. Próba polityki starości, [w:] Egzystencjalne doświadczenie starości w literaturze, red. A. Gleń, I. Jokiel, M. Szladowski, Opole 2008.

Sławęcka E., Inspiracje naturalistyczne w twórczości Aleksandra Kuprina, [w:] Zagadnienia prądów i kierunków w literaturze rosyjskiej, red. S. Poręba, Katowice 1980.

Starość. Wybór materiatów z VII konferencji Pracowników Naukowych i Studentów Instytutu Nauk o Literaturze Polskiej UŚ, red. A. Nawarecki, A. Dziadek, Katowice 1995.

Szladowski M., Starość w przedsionku śmierci (zamiast wstępu), [w:] Egzystencjalne doświadczenie starości w literaturze, red. A. Gleń, I. Jokiel, M. Szladowski, Opole 2008.

Trybuś K., Stary poeta. Studia o Norwidzie, Poznań 2000.

Trzeci wiek drugiej ptci. Starsze kobiety jako podmiot aktywności społecznej i kulturowej, red. E. Zierkiewicz, A. Łysak, Wrocław 2006.

Uzar K., Wychowanie w perspektywie starości: personalistyczne podstawy geragogiki, Lublin 2011. Дружников Ю., Куприн в дегте и патоке, „Новое русское слово”, 24.02.1989.

Куприн А., Собрание сочинений в девяти томах, т. 1-5, ред. Н. Акопова, Ф. Кулешов, Н. Куприна, А. Мясников, Москва 1971-1972.

Переписка И.Е. Репина и А.И. Куприна, публикация и комментарии К. Куприной, „Новый мир" $1969, \mathrm{nr} 9$.

Письма А.И. Куприна к И.А. Левинсону (1928-1934 г2.), [w:] К.Н. Батюшков, Ф.Д. Батюшков, А.И. Куприн. Материаль всероссийской научной конференции в Устюжне о жизни и творчестве Батюшковых и Куприна (28-29 сентября 1966 года), публикация и комментарии П. Ширмакова, Вологда 1968.

Седых А., А.И. Куприн, http://www.a-port.us/gene/story/seduh.htm.

Ташлыков С., А.И. Куприн: поэтика новелль, Иркутск 2012.

Тэффи Н., Моя летопись, http://www.vek-serebra.ru/teffi/moia_letopis.htm. 


\section{The nature of old age in Aleksandr Kuprin's short stories}

\section{Summary}

Aleksandr Kuprin, writing at the turn of the twentieth century, joins the old age discourse of his time. Old age (or maturity) in Kuprin's works has different faces (kind-hearted, wise, respected, embittered, rejected, lonely, etc.) and is presented in various contexts: cultural, social, economic. From old age inspirations the writer creates both pictures and naturalistic reflexions (descriptions of anatomical and physiological changes), and metaphysical (passing, asking about the meaning of life). Additionally, Kuprin depicts the antinomy: early days - old age, compares advanced age to childhood and analyzes the symptoms of not only somatic but also mental old age.

Keywords: Kuprin, old age, early days, loneliness, physiological processes, passing

\section{Лики старости в рассказах Александра Куприна}

Резюме

Александр Куприн, творивший на рубеже XIX и XX веков, включается в тогдашний дискурс старости. Старость (или зрелость) принимает в его творчестве разные облики (добрая, умная, почтенная, озлобленная, отвергнутая, одинокая и т.д.) и изображается им в разных контекстах: культурном, общественном и экономическом. Она вдохновляет писателя как на создание натуралистических образов (изображение анатомических и физиологических изменений), так и наталкивает на метафизические размышления (ход времени, смысл жизни). Кроме того, прозаик рассматривает антиномию: молодостьстарость, сопоставляет преклонный возраст с детством, подвергает анализу симптомы как физической, так и духовной старости.

Ключевые слова: Куприн, старость, молодость, одиночество, физиологические процессы, ход времени

Slavica Wratislaviensia 163, 2016

(C) for this edition by CNS 